\title{
Factors Influencing Adoption and Usage of Mobile Banking: Bangladesh Experience
}

\author{
Sadia Noor Khan ${ }^{1}$, Maimuna Akter ${ }^{1}$, Rozina Akter ${ }^{2}$ \\ ${ }^{1}$ Department of Banking and Insurance, University of Dhaka, Dhaka, Bangladesh \\ ${ }^{2}$ Department of Business Administration, Daffodil International University, Dhaka, Bangladesh
}

Email address:

sadiakhandu_14@yahoo.com (S. N. Khan), maimuna.du@gmail.com (M. Akter), Rod.mila@yahoo.com (R. Akter)

\section{To cite this article:}

Sadia Noor Khan, Maimuna Akter, Rozina Akter. Factors Influencing Adoption and Usage of Mobile Banking: Bangladesh Experience. International Journal of Finance and Banking Research. Vol. 3, No. 1, 2017, pp. 1-12. doi: 10.11648/j.ijfbr.20170301.11

Received: July 26, 2016; Accepted: October 28, 2016; Published: March 17, 2017

\begin{abstract}
The main objective of the present study is to investigate the factors, demographic variables and users' perception, that influence the adoption of mobile banking in Bangladesh. The study also discusses the status of mobile banking usage using age, gender, and occupation as demographic variables, and the perception of users toward mobile banking in terms of trustworthiness, security, cost and convenience, complexity, and network availability. It includes specific reference to how these demographic variables and users' perception influence mobile banking usage. A self administered questionnaire has been developed to conduct a survey on a sample of 400 mobile banking users for a period of 4 years i.e. 2012 to 2015 . Analysis has revealed that majority of the users are male and students of age 20-24 years. They perceive mobile banking to be trustworthy, secured and cost effective, though complex and vulnerable to network problem. Using panel regression analysis the study has revealed that differences in demographic characteristics have no influence over mobile banking adoption. It has also revealed that perception to security, cost and convenience, and complexity in using mobile banking service influences variations in mobile banking adoption. Conversely, perception to trustworthiness and network problem has been found to have no influence; however, it has been found to have influence on mobile banking adoption using score model assessment.
\end{abstract}

Keywords: Mobile Banking, Demographic Characteristics, Users’ Perception

\section{Introduction}

There are currently 1.75 billion smart phone users in the world and the total number of mobile phone subscriptions has reached 121.860 million at the end of January 2015 in Bangladesh. Bangladesh is, in many ways, a country in advance of its time in terms of mobile access. Even though being ranked as a low income country, over $50 \%$ of the population subscribes to mobile services and has outpaced all its peers in terms of network coverage. The amalgamation of limited disposable income and further mature mobile usage means the customers of Bangladesh are more perceptive. Mobile phone is a blessing of the technology which is serving immensely to attain the unbanked population. The stipulation of banking services to customers on their mobile devices particularly the function of bank current deposit or savings accounts is defined as mobile banking (Sharma 2012). Mobile banking also known as M-Banking /m- banking, SMS Banking can be used for checking balance, account transactions, payments, credit applications and other banking transactions. Through mobile messaging, banks offer value added services to the customer at marginal costs. It is a quite popular method of banking that fits in well with a busy technically oriented lifestyle. Anywhere/anytime a characteristic of mobile services is another benefit of mobile banking. A mobile is more or less always with the customer. Users can use it over a gigantic geographical area. The customer does not have to visit the bank ATM or a branch to avail of the bank's services (Goyal 2012). The convenience, privacy, time and effort savings together with the locationfree access that $\mathrm{m}$-banking offers encourage its adoption and usage (Suoranta 2003). Whereas self-prestige and awareness are the key factors in m-banking adoption and usage (Lee et al, 2003). These idiosyncratic features have made the mobile banking to grow further. Many banks of Bangladesh are progressively realising that there are indeed massive opportunities to be tapped with the mobile banking. 


\subsection{Mobile Banking in Bangladesh}

Financial Inclusion through extending financial services to the remotest areas has been an enigma, especially when it involves designing a profitable model. But this seemingly utopian scheme has been remarkably accomplished in Bangladesh, the globally reputed powerhouse of banking to the poor, especially to the micro entrepreneurs. Mobile banking in Bangladesh is very young. In 2012 Dutch-Bangla Bank Limited (DBBL) has for the first time introduced its mobile banking service expanding the banking service from cities to remote areas in Bangladesh. This service was inaugurated by the Bangladesh Bank Governor Atiur Rahman by depositing
Tk 2,000 and withdrawing Tk 1,500 through Banglalink and Citycell mobile networks. Mobile banking service started its operation in full fledges from 2014. Right now 28 banks have the license of doing mobile banking by their branches and many banks are waiting for authorization. Even though 28 banks have license but 19 banks are providing mobile banking services. Moreover the number of agent is 538,170 around the country where the total registered client is 286.46 lac and active account is 122.34 lac with total transaction $\mathrm{Tk}$ $12,969.51$ crore. The average daily transaction is about Tk 432.31 crore that's huge for a country like Bangladesh. The growth rate of mobile banking of Bangladesh from different perspectives has been given in table 1 .

Table 1. m BANKING GROWTH.

\begin{tabular}{|c|c|c|c|c|c|c|}
\hline & \multicolumn{2}{|l|}{ MFS accounts } & \multicolumn{2}{|l|}{ Transactions } & \multicolumn{2}{|l|}{ Agents } \\
\hline & Number (Million) & Growth & Number (USD Million) & Growth & Number & Growth \\
\hline 2011 & 0.44 & & 26.67 & & 9093 & \\
\hline 2012 & 2 & $355 \%$ & 256.7 & $863 \%$ & 59559 & $555 \%$ \\
\hline 2013 & 13 & $550 \%$ & 847.2 & $230 \%$ & 82000 & $38 \%$ \\
\hline 2014 & 25.25 & $94 \%$ & 1345.6 & $59 \%$ & 540948 & $560 \%$ \\
\hline Average Growth & & $264 \%$ & & $227 \%$ & & $227 \%$ \\
\hline
\end{tabular}

The stunning statistics of nearly $264 \%$ mobile banking growth rate over the last four year bears testimony to the fact that mobile banking has enabled almost everyone with any handset to transact, regardless of the distance across the country. This paper examines the key factors instrumental to this salient revolution in Bangladesh that can be a replicable model to other parts of the world, specially the neighboring India.

Performance comparison of leading mobile banking providers: Right now 19 service providers are offering mobile banking services in Bangladesh. Most of them have commenced their journey after 2012. Some pioneer banks are getting competitive advantages. DBBL and bKash mobile banking has brought a huge number of people under banking services within very short period of time. bKash of BRAC bank beats DBBL on a large scale though it has started its operation one year later. The branding of the service name and intense marketing effort has helped them to achieve huge market share within very short period. The number of agent of bKash is around 20\% higher than DBBL and number of client is almost four times greater than that of DBBL.

Table 2. Present Scenario Of Agents And Clients In Leading Mobile Banking Provider

\begin{tabular}{lll}
\hline Name of services & Number of agents & Number of clients \\
\hline bKash & 80000 & 80.1 million \\
DBBL MB & 62572 & 2010283 \\
mCash & 61000 & 150000 \\
TBMM & 20000 & 100000 \\
uCash & 10000 & 90000 \\
mPay & 8000 & 51000 \\
Primecash & 3000 & 100000 \\
\hline
\end{tabular}

The comparison of financial inclusion and mobile banking data of Bangladesh, India, and Pakistan, as illustrated in figure 1 in the next page, suggests that the financial inclusion percentage of these countries stand close. But mobile banking is the area India is lagging substantially, comparing to her neighbors.

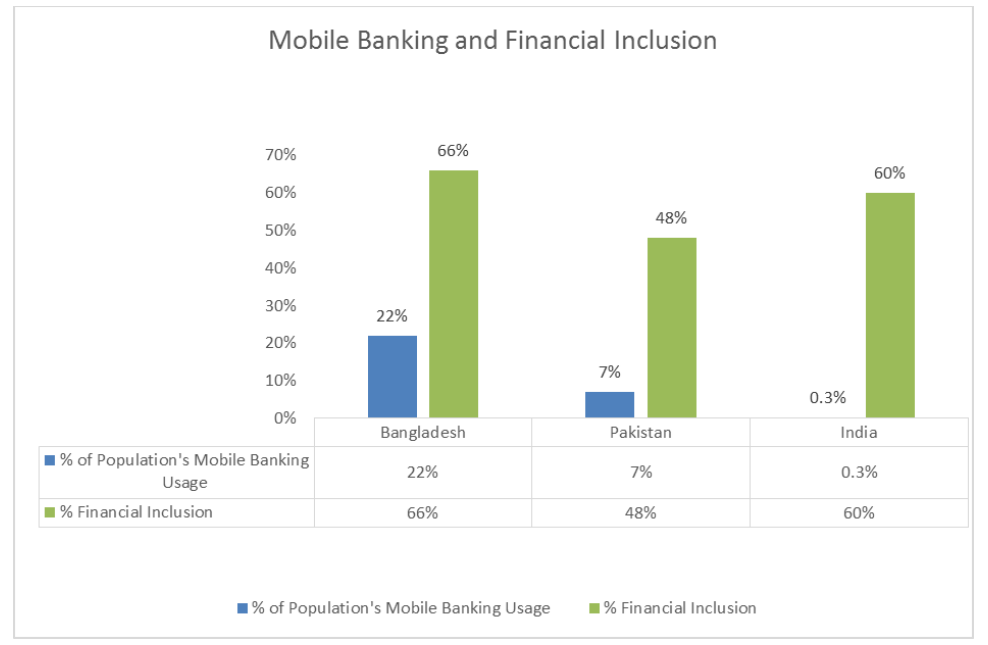

Figure 1. Neighboring country comparison on m banking. 
The silent revolution of Bangladesh experience of mobile baking's phenomenal growth can be a replicable model which demands further examination and scrutinizing of the underlying driving factors contributing to an unconventional financial inclusion and payment mechanism, with a minimal and affordable cost. This paves the way for people of every income stratum to avail financial services and enables them to transact through a profitable model for all the stakeholders involved.

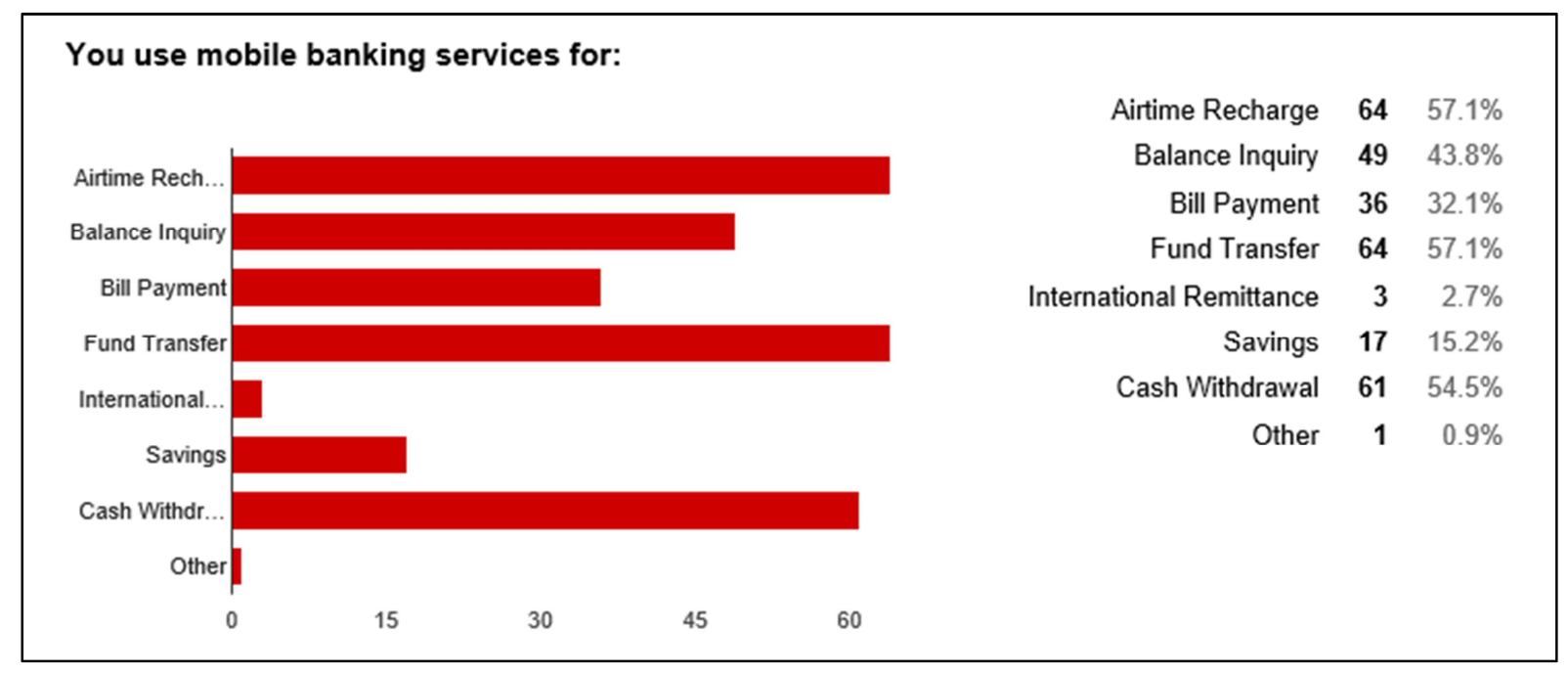

Figure 2. User Profile.

\subsection{Objectives of the Research}

Broad Objective: The main objective of the study is to examine the factors affecting the adoption of mobile banking in Bangladesh and analyze these factors by using sophisticated statistical tools. Specifically objectives of this research are:

- To identify factors influencing the adoption and usage of mobile banking in Bangladesh.

- To explain how the demographic variables elucidate the adoption of mobile banking in Bangladesh.

- To examine the relationship between Mobile Banking Usage Score and the five underlying factors.

\subsection{Literature Review}

Literatures show very few studies conducted on mobile banking. Majority of the studies have been conducted on developing countries. The studies concentrate on the areas like problems and prospects of mobile banking, factors influencing the growth of mobile banking adoption etc. Sharma and Kansal (2012) stated some problems that customers face while conducting mobile banking. They found that the adoption rate of mobile banking is far behind than the pace of technology advancement. Complications in functionality and privacy related issues cause customers feel doubtful about the convenience and security of using mobile banking service. In addition, banks cannot provide updated service according to need of customers because of excessive cost and competitiveness.

Nandhi (2012) conducted a study on 160 customers in Delhi. He concluded that the ability of customers to save has increased with mobile banking service due to higher safety compared to keeping cash on hand, avoidance of wasteful expenses and convenience relating small and frequent saving facility. He also concluded mobile banking to be more secured mode of saving to the low income people compared to some informal saving practices (keeping cash at home, under the mattress, or with person). Goyal et al (2012) made a review of the emerging research literature on mobile banking. The study found that sex is the only demographic factor that influences use of mobile banking service and concluded that male are more inclined to use mobile banking service compared to female. It also concluded that most of the people (users and non-users) are indifferent about utility of mobile banking service. In contrary, Ramdhony and Munien (2013) found that mobile banking usage is not associated with age and gender. However, they found that the usage has a high association with education level of user. Their study revealed that though convenience, time and cost effectiveness, and ubiquitous access to banking service cause higher awareness among mobile banking users in Mauritius, perceived security risk and reliability is still hindering the growth of mobile banking.

Very few studies have been conducted on Bangladesh regarding mobile banking. Most of the studies focused on the usage, problems and prospects of mobile baking. The literature lacks in the areas like customer satisfaction, growth and influencing factors over mobile banking usage. Alam et al (2013) gave an overview of the cost, benefits and usage of mobile banking in Bangladesh. Kabir (2013) conducted a study on Bangladesh where the response rate was 64 percent. The study was on the factors influencing the users of regular banking service to use mobile banking service. He found that perceived risk is the main impediment toward the acceptance of mobile banking in Bangladesh. A similar finding was stated by Saini (2014) in his study conducted on Delhi. 
Rahman (2013) conducted a study on 'Implementation of Mobile Banking in Bangladesh: Opportunities and Challenges' and found that, almost all of the users of mobile banking use checking balance option and fund transfer, fund withdrawal and mobile balance recharge follow it. Author also found that, the growth of mobile banking is almost $100 \%$ from previous year and it will even increase more if banks are more careful about their service. Out of 47 respondents about $53.2 \%$ believe that mobile banking is highly secured while $38.30 \%$ believe that it is fairly secured. In case of accessing others account using PIN, about $28.26 \%$ believe it to be very easy out of 48 respondents while $19.56 \%$ believe fairly easy, $10.87 \%$ believe neither difficult nor easy and $19.56 \%$ believe very difficult.

Islam (2013) conducted a study on 'Mobile Banking: An Emerging Issue in Bangladesh' and found that mobile banking can be conducted from anywhere in the country any time so it is saving lots of time of the users. In addition to this, mobile banking is also cost efficient compared to traditional banking and the security system of mobile banking is high as it requires a PIN code to access one's account. Moreover, the author also found from his study, mobile banking is considering poorer sector's contribution in the economy while traditional banking is ignoring the poor people's contribution as their transaction is of small amount. From the empirical study, the author found that, about $95 \%$ people have mobile phone and 54\% respondents believe that mobile banking is less costly and time saving, $63 \%$ of them have full trust on the mobile banking system and $83 \%$ think that it is easier to use.

\subsection{Research Design}

- Research Type: Descriptive

- Types of Data: Primary and Secondary.

- Study Period: Year 2012 to year 2015.

- Sampling Design Process: Questionnaire for both male $\&$ female users.

- Target Population: Account holders of the scheduled banks of Bangladesh.

- Sampling Technique: Convenience Sampling.

- Sample Size: 400 Sampling frame Directory.

- Demographic profile: Shown in table 4 and table 5.

Table 3. Demographic Profile Of The Survey: Age And Gender.

\begin{tabular}{llll}
\hline & Age Limit & Frequency & Percent (\%) \\
\hline $15-19$ & 28 & 7.08 \\
$20-24$ & 225 & 56.31 \\
& $25-29$ & 76 & 19.08 \\
Age & $30-34$ & 33 & 8.31 \\
& $35-39$ & 18 & 4.31 \\
& $40-44$ & 10 & 2.46 \\
& $45-49$ & 10 & 2.46 \\
Gender & Male & 319 & 79.69 \\
& Female & 81 & 20.31 \\
\hline
\end{tabular}

Table 4. Demographic Profile Of The Survey: Occupation.

\begin{tabular}{llll}
\hline & Description & Frequency & Percent (\%) \\
\hline Occupation & Business & 56 & 13.85 \\
& Service Holder & 71 & 17.54 \\
& Student & 268 & 67.08 \\
& Doctor & 2 & 0.62 \\
& Garment & 1 & 0.31 \\
& Housewife & 2 & 0.62 \\
\hline
\end{tabular}

- Method of Administering Questionnaire: Personal interview.

- Types of questions asked: Structured Questions (Multiple Choice Questions \& Open Ended Questions).

- Interviewing time: 15 minutes.

- Field work \& data collection: For the research and data analysis purposes the authors have collected the needed data through survey method.

\subsection{Research Methodology}

The methodology used in this paper has been given as follows-

- Descriptive Statistics: Mean, Median, Mode, Standard deviation of demographic profile and user's perception has been analyzed in this research paper.

- Formulation of Hypothesis: Following hypotheses have been developed by the authors for analysis.

Hypothesis 1:

Influence of demographic factors on mobile banking adoption

The main demographic factors to show their influence on mobile banking adoption are gender, age and occupation. Hence, it is shown how the percentage of male users contributes to the adoption rate of mobile banking. In addition, how generation contributes to acceptance of mobile banking.

Ho: Demographic profile does not have influence over rate of mobile banking adoption

H1: Demographic profile has influence over rate of mobile banking adoption

To support the above hypothesis two simultaneous hypotheses are drawn.

Ho: Age of user does not have contribution to the rate of mobile banking adoption

H1: Age of user has contribution to the rate of mobile banking adoption

$\mathrm{H} 0$ : Gender of user does not have contribution to the rate of mobile banking adoption

H1: Gender of user has contribution to the rate of mobile banking adoption

Ho: Occupation of user does not have contribution to increase the rate of mobile banking adoption

$\mathrm{H} 1$ : Occupation of user has contribution to increase the rate of mobile banking adoption

Dependent variables: Number of mobile banking accounts of last four years

Independent variables: 
- Trend of people of different age limits using mobile banking service for last four years

- Trend of people of different genders using mobile banking service for last four years

- Trend of people of different occupations using mobile banking service of last four years

Influence of users perception on mobile banking adoption

Hypothesis 2 .

H0: Users' perception does not have any influence over rate of mobile banking adoption

H1: Users' perception has influence over rate of mobile banking adoption

Dependent variables: Number of mobile banking accounts of last four years.

Independent variables: Users' changing perception regarding trust, security, cost and convenience, complexity and network problem over mobile banking usage.

- Data analysis

Data are analyzed using SPSS Version 20 to draw relationship between the dependent variable and independent variable. Hypotheses are drawn to show influence of demographic profile of customers and their perception on rate of mobile banking adoption for last four years. Significance level of. 1 is used to determine the significance of models.

- Regression analysis

Each factor of demography and perception is used individually to draw their effect on rate of mobile banking adoption. Since independent variables have multicollinearity problem (See Appendix A), linear regression is used instead of multiple regression for each factor of independent variable.

- Relationship between Mobile Banking Usage Score and the five underlying factors

Methodology: Usage Score Model

Usage Score = Usage Types X Usage Frequency

Usage Types: The number of using pattern out of the options below represents the scale of usage ranging from 0 to 7 .

\begin{tabular}{|c|c|}
\hline$: \square$ & Airtime Recharge \\
\hline$\square$ & Balance Inquiry \\
\hline$: \square$ & Bill Payment \\
\hline$\square$ & Fund Transfer \\
\hline$\square$ & International Remittance \\
\hline : $\square$ & Savings \\
\hline$\square$ & Cash Withdrawal \\
\hline
\end{tabular}

Figure 3. Usage Types.
Frequency-wise weight $=$ IF (Frequency $=$ "Occasionally", 0.5, IF (Frequency="Once in a day", 30, IF (Frequency $=$ "Once in a month", 1, IF (Frequency =Once in a week", 4, IF (Frequency="Several time in a week", 14, IF (Frequency="Several time in a day", 45, IF (Frequency $=$ "Twice or thrice in a month", 2.5)))))))

\subsection{Theoretical Framework}

Factors Influencing Adoption and Usage of Mobile Banking: Bangladesh Experience

So, we are describing the influence of some factors on consumers' adoption and usage of $\mathrm{M}$ Banking. Here, the factors are independent variables, and the adoption and usage is dependent variables.

The operational definitions of the chosen independent variables are as follow.

1) Trust: In this study, TRUST means a consumer's belief that his/her privacy regarding personal and transaction information (which are accessible to the Bank, and the Operator) will not be harmed, and the technology is reliable enough to protect his/her private information from unauthorized parties (e.g. hackers).

A consumer will adopt the M Banking services, only when s/he will have trust in the bank, operator, and the technical system.

2) Security: In this study, SECURITY means a consumer's belief that his/her money can be securely saved and transferred using $\mathrm{M}$ Banking.

A consumer will adopt and use M Banking, only when s/he is convinced that the money to be saved or transferred will be safe from theft.

3) Convenience: In this study, CONVENIENCE means the consumer find using $\mathrm{M}$ Banking more beneficial than traditional banking or cash-in-hand practices in terms of time saving, transportation cost saving, facilitating of small fund transfer, and ease of saving.

A consumer will adopt $M$ Banking when s/he will find it saves time, money, make transaction and saving easier.

4) Complexity: In this study, COMPLEXITY means the degrees to which a consumer find the processes of depositing, and transferring fund difficult to understand, and annoying (I wanted to say hasslesome) to execute.

A consumer won't use a technology that s/he can't understand or finds too annoying.

5) Network Availability: I could not define it. Also, can't develop the likert indicator for it. 
Adoption of Mobile Banking:
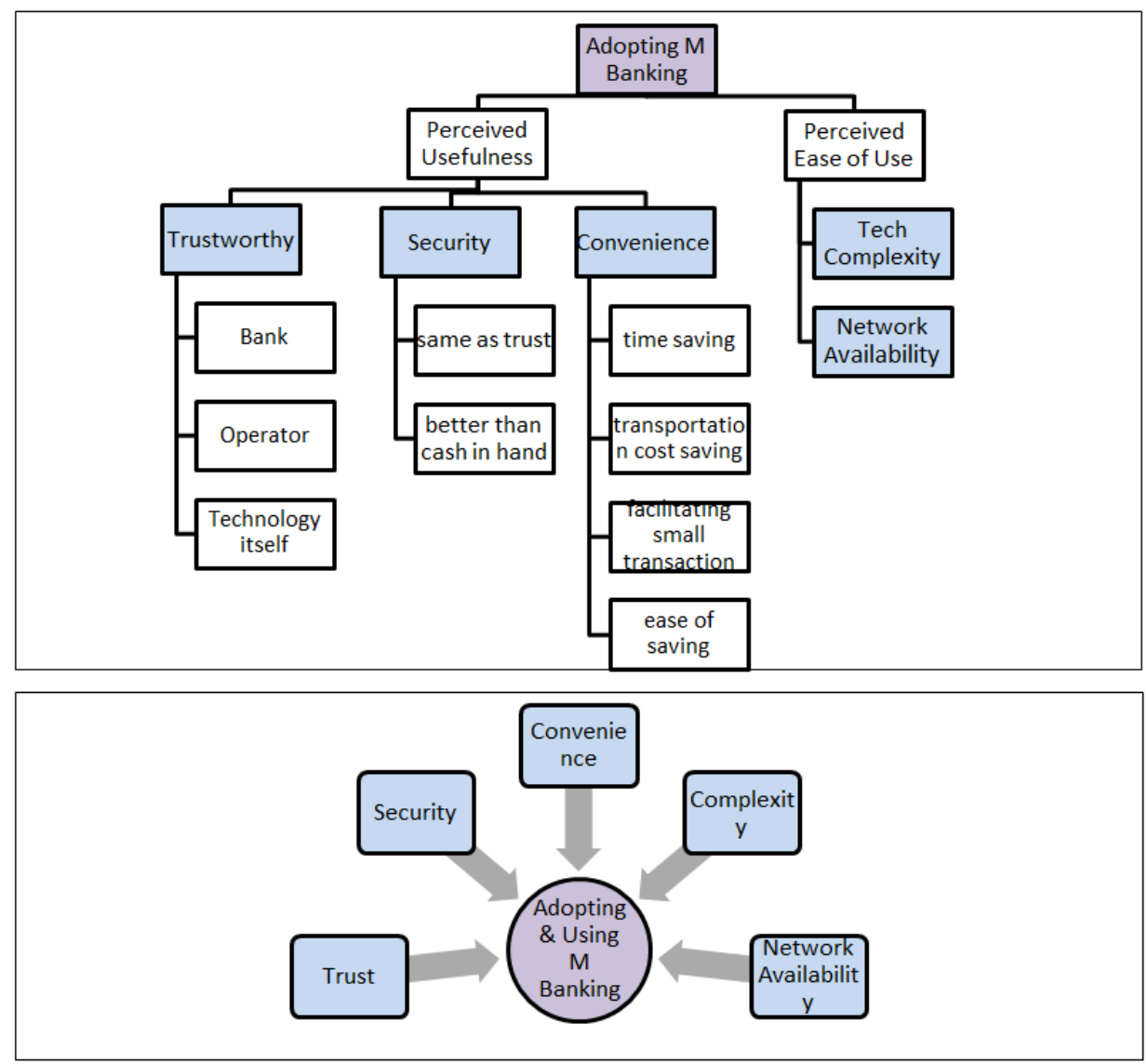

Figure 4. Adoption of Mobile banking.

The following diagrams picture the relationship between the variables, and the associated indicators.

This model doesn't take into account the actual technological and policy changes in the industry, which also influences adoption and usage of M Banking. However, the first part of the questionnaire will identify the respondents as user or non user, and reveal usage frequency of a user. Qualitative comparison of responses of different user profiles can reveal strong insights.

\section{Data Analysis and Discussion}

\subsection{Analysis of Descriptive Statistics}

Table 5. Age Wise Usage Of Mobile Banking

\begin{tabular}{lllll}
\hline $\begin{array}{l}\text { Age } \\
\text { limits }\end{array}$ & $\begin{array}{l}\text { Frequency over } \\
\text { study period }\end{array}$ & Percentage & & \\
\hline $15-19$ & 28 & 7.08 & Mean & 24.9220 \\
$20-24$ & 225 & 56.31 & Mode & 22.0000 \\
$25-29$ & 76 & 19.08 & Median & 22.0000 \\
$30-34$ & 33 & 8.31 & Std Deviation & 7.11762 \\
$35-39$ & 17 & 4.31 & & \\
$40-44$ & 10 & 2.46 & & \\
$45-49$ & 11 & 2.75 & & \\
\hline
\end{tabular}

Table 6 shows that among the total number of mobile banking users, users of age 20-24 occupy a major portion. The average age of people using mobile banking is 24-25. The standard deviation seems to be high that indicates huge dispersion among the age of users as mobile banking is not only confined to the people of particular age, it is now convenient to people from all age limits.

Table 6. Gender Wise Usage Of Mobile Banking.

\begin{tabular}{lll}
\hline Gender & Frequency & Percentage \\
\hline Male & 319 & 79.69 \\
Female & 81 & 20.31 \\
\hline
\end{tabular}

The table 7 drawn using results of frequency distribution shows that male users occupy almost $80 \%$ of total market. In Bangladesh, male seems to be more engaged to different jobs, educational institutions, business than female.

Table 7. Occupation Wise Usage Of Mobile Banking

\begin{tabular}{lll}
\hline Occupation & Frequency & Percentage \\
\hline Business & 55 & 13.75 \\
Service Holder & 70 & 17.5 \\
Student & 268 & 67 \\
Doctor & 2 & 0.5 \\
Garment & 3 & 0.75 \\
Housewife & 2 & 0.5 \\
\hline
\end{tabular}

The table 8 shows that students hold a major portion of 
total customers in market with a rate of $67 \%$. Service holders also occupy a huge percentage of almost $18 \%$. Most of the students who study far away from their home are dependent to their parents for expenses. Hence their proportion to total user is higher than that of other users.

Table 8. Perception To Trust.

\begin{tabular}{lllll}
\hline Responses & Frequency & Percent & & \\
\hline Strongly Disagree $=1$ & 21 & 10.2 & Mean & 3.1512 \\
Disagree=2 & 48 & 23.4 & Median & 3 \\
Neutral=3 & 38 & 18.5 & Mode & 4 \\
Agree=4 & 75 & 36.6 & Std. Deviation & 1.20113 \\
Strongly agree $=5$ & 23 & 11.2 & & \\
Total & 205 & 100.0 & & \\
\hline
\end{tabular}

In response to the statement- "There is no chance of leakage of my personal and transactional information", majority (36.6\%) of the respondents showed their agreement. As there are very few cases regarding such malfunction and mobile banking seems to be easy to use, majority of the users see mobile banking as trustworthy. The standard deviation of 1.20113 shows that comparatively less dispersion in response to the statement.

Table 9. Perception To Security.

\begin{tabular}{lllll}
\hline Responses & Frequency & Percent & & \\
\hline Strongly disagree= $=1$ & 7 & 3.4 & Mean & 3.3951 \\
Disagree= 2 & 36 & 17.6 & Median & 4 \\
Neutral= 3 & 58 & 28.3 & Mode & 4 \\
Agree=4 & 77 & 37.6 & Std. Deviation & 1.03136 \\
Strongly Agree $=5$ & 27 & 13.2 & & \\
Total & 205 & 100.0 & & \\
\hline
\end{tabular}

In response to the statement- "Hackers can transfer my money to their accounts, without making the bank and operator security systems aware", almost 38\% respondents agreed with the statement. As people of Bangladesh are very much conscious about security and moral hazard, majority them think it to be less secured due to lack of knowledge over mobile banking. The standard deviation is relatively low with 1.03136 which shows less variability among the perception of the users of mobile banking.

Table 10. Perception To Cost And Convenience.

\begin{tabular}{lllll}
\hline & Frequency & Percent & \\
\hline Strongly disagree= 1 & 9 & 4.4 & Mean & 3.5512 \\
Disagree= 2 & 23 & 11.2 & Median & 4 \\
Neutral=3 & 47 & 22.9 & Mode & 4 \\
Agree $=4$ & 98 & 47.8 & Std. Deviation & 1.00553 \\
Strongly Agree $=5$ & 28 & 13.7 & & \\
Total & 205 & 100.0 & & \\
\hline
\end{tabular}

In response to the statement- "It is better to pay some service charge in M Banking than spending on conveyance to make a payment, or transfer a fund to someone", majority (almost 48\%) concluded mobile banking to be cost effective and convenient as it causes very little cost and inconvenience to users. The standard deviation of 1.00553 shows little deviation among the perception of users regarding cost and convenience of mobile banking.

Table 11. Perception To Complexity.

\begin{tabular}{|c|c|c|c|c|}
\hline & Frequency & Percent & & \\
\hline Strongly disagree $=1$ & 16 & 7.8 & Mean & 2.8244 \\
\hline Disagree $=2$ & 73 & 35.6 & Median & 3 \\
\hline Neutral $=3$ & 61 & 29.8 & Mode & 2 \\
\hline Agree $=4$ & 41 & 20.0 & Std. Deviation & 1.05644 \\
\hline Strongly Agree $=5$ & 14 & 6.8 & & \\
\hline Total & 205 & 100.0 & & \\
\hline
\end{tabular}

In response to the statement- "I find the operation processes (depositing \& withdrawing money, transferring fund) too complex to understand", majority (almost 36\%) respondents were neutral. Though convenient to use, mobile banking seems still complex to some of people in Bangladesh as they are technologically less advanced and are habituated to paper work. The standard deviation of 1.05644 shows little dispersion regarding the perception over complexity.

Table 12. Perception To Ambiguous Network Availability.

\begin{tabular}{lllll}
\hline & Frequency & Percent & & \\
\hline Strongly disagree $=1$ & 14 & 6.8 & Mean & 3.2341 \\
Disagree= $=$ & 43 & 21.0 & Median & 3 \\
Neutral= 3 & 48 & 23.4 & Mode & 4 \\
Agree $=4$ & 81 & 39.5 & Std. deviation & 1.09536 \\
Strongly Agree $=5$ & 19 & 9.3 & & \\
Total & 205 & 100.0 & & \\
\hline
\end{tabular}

In response to statement- "Operating an $\mathrm{M}$ bank a/c often becomes tougher because of unavailability of mobile operator network", majority (almost 40\%) showed their agreement. Though telecom companies are now covering major portion of Bangladesh, network problem is still remaining in pick hours. Therefore, mobile banking transactions often get hampered. The standard deviation of 1.09536 shows little dispersion of the perception of mobile banking users regarding network problem during transaction.

Findings and discussion from descriptive statistics: Analysis of the descriptive statistics shows that people of age 20-24 are the major users of mobile banking in Bangladesh as most of the users of mobile banking are students of age 20-24. In addition, it shows that male are more engaged to mobile banking than female as they are more engaged to different jobs, educational institutions etc. Majority of the users perceive mobile banking to be trustworthy, secured and cost effective. On the other hand, they perceive it to be complex and vulnerable to network problem.

\subsection{Mobile Banking Users: Demographic Profile}

\subsubsection{Analysis of Demographic Profile}

The survey has been conducted with some basic information of the respondents. Respondents were asked about their age, gender and occupation. Their information with percentages is found out from the frequency distribution, and these are shown in pie charts. 


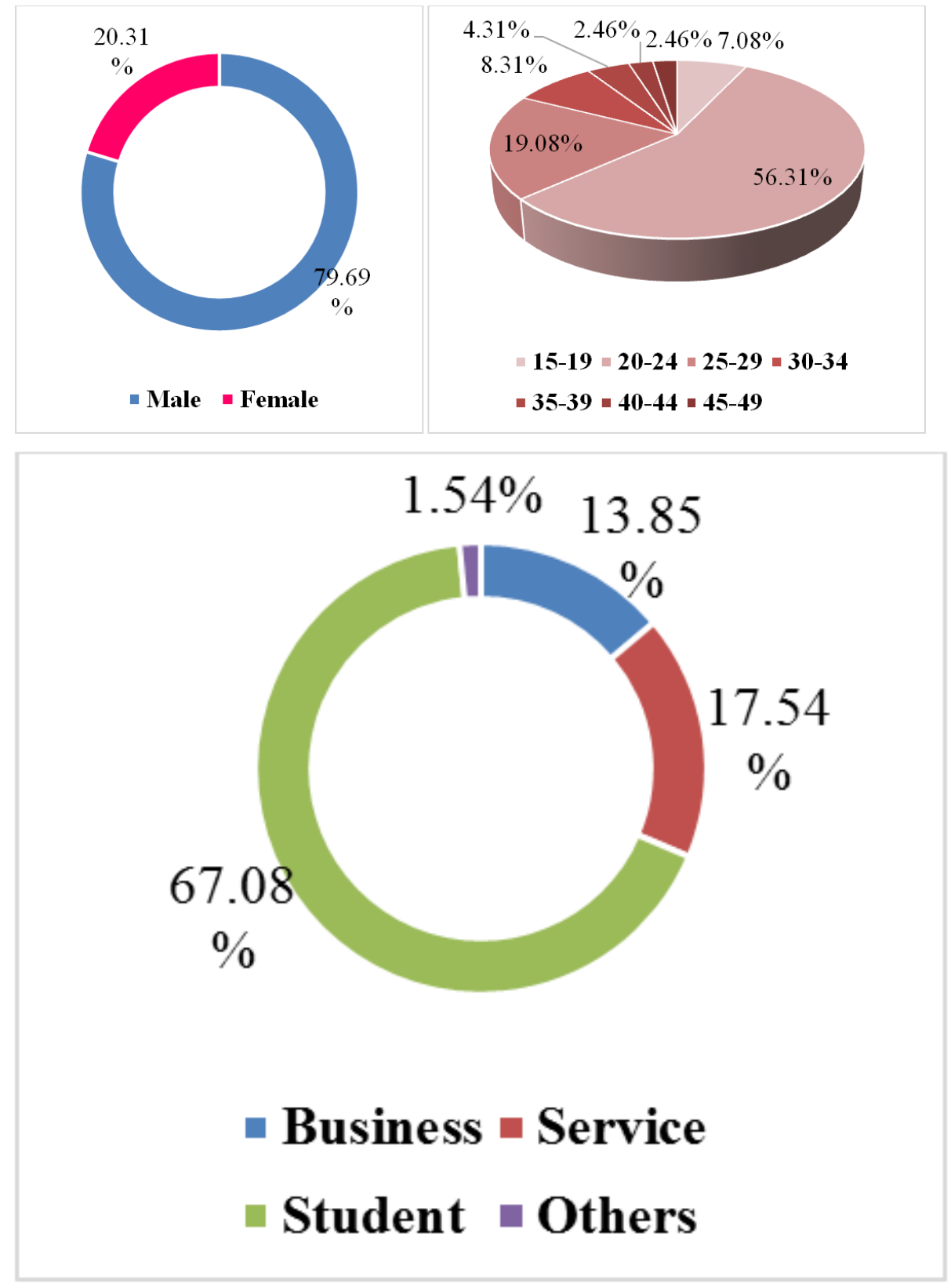

Figure 5. Gender (\%), Age (\%) And Occupation (\%) Of Surveyed Sample.

\subsubsection{Regression Analysis of Demographic Profile}

Regression analysis has been conducted to find out the relationship between adoption and usage of mobile banking in Bangladesh and the demographic variables such as age, gender and occupation. Table 2.3, 2.4 and 2.5 shows the regression output of relationship between adoption of mobile banking and demographic profile.

Hypothesis 1:

Hypothesis 1 is developed to show the influence of users' demographic profile on mobile banking adoption. Using the data of dependent and independent variables of last four years two simultaneous hypotheses have been tested to test Hypothesis 1.
Table 13. Influence Of Gender Over Rate Of Mobile Banking Adoption.

\begin{tabular}{lll}
\hline & Percentage of male & Percentage of female \\
\hline Rate of mobile & $\mathrm{b}=-.746$ & $\mathrm{~b}=.746$ \\
banking & $\mathrm{R}^{2}=.296$ & $\mathrm{R}^{2}=.296$ \\
adoption & $(P=.456)$ & $(P=.456)$ \\
\hline
\end{tabular}

The results of linear regression run with both female and male users show that neither of the gender has contribution to the increase of mobile banking usage in last four years. Hence the models used to show the dominance of a particular gender over mobile banking usage are non significant as their $p$ values are higher the significance level of.1. In addition, $\mathrm{R}^{2} \mathrm{~S}$ are too poor in both the cases. 
Table 14. Influence Of Age Limit On Rate Of Mobile Banking Adoption.

\begin{tabular}{lllll}
\hline & $\mathbf{1 5 - 1 9}$ & $\mathbf{2 0 - 2 4}$ & $\mathbf{2 5 - 2 9}$ & $\mathbf{3 0 - 3 4}$ \\
\hline Rate of & $\mathrm{b}=4.395$ & $\mathrm{~b}=-.813$ & $\mathrm{~b}=.660$ & $\mathrm{~b}=2.958$ \\
mobile banking & $\mathrm{R}^{2}=.292$ & $\mathrm{R}^{2}=.641$ & $\mathrm{R}^{2}=.062$ & $\mathrm{R}^{2}=.529$ \\
adoption & $(P=.460)$ & $(P=.199)$ & $(P=.751)$ & $(P=.272)$ \\
& $35-39$ & $40-44$ & $45-49$ & \\
& $\mathrm{~b}=3.798$ & $\mathrm{~b}=5.781$ & $\mathrm{~b}=3.262$ & \\
& $\mathrm{R}^{2}=.800$ & $\mathrm{R}^{2}=.421$ & $\mathrm{R}^{2}=.664$ & \\
& $(P=.106)$ & $(P=.351)$ & $(P=.185)$ & \\
\hline
\end{tabular}

The results depicted in the table developed with the result of regression show that though the age limit 20-24 occupies a major proportion of the total mobile banking users in Bangladesh, none of the age limits does not have particular influence to the total increase of mobile banking adoption rate in Bangladesh. The conclusion is made using the $p$ value, significantly higher than the significance level of.1. In addition, $\mathrm{R}^{2}$ values are so poor to determine the variability in the dependent variable caused by independent variables.

Table 15. Influence of occupation on rate of mobile banking adoption

\begin{tabular}{lllll}
\hline & Businessman & $\begin{array}{l}\text { Service } \\
\text { Holder }\end{array}$ & Student & Doctor \\
\hline & $\mathrm{b}=3.862$ & $\mathrm{~b}=.519$ & $\mathrm{~b}=-.619$ & $\mathrm{~b}=20.103$ \\
Rate of & $\mathrm{R}^{2}=.639$ & $\mathrm{R}^{2}=.218$ & $\mathrm{R}^{2}=.390$ & $\mathrm{R}^{2}=.764$ \\
mobile & $(P=.201)$ & $(P=.533)$ & $(P=.375)$ & $(P=.126)$ \\
banking & Garment Workers & Housewife & Unemployed & \\
adoption & $\mathrm{b}=20.103$ & $\mathrm{~b}=1.885$ & $\mathrm{~b}=-.915$ & \\
& $\mathrm{R}^{2}=.764$ & $\mathrm{R}^{2}=.027$ & $\mathrm{R}^{2}=.006$ & \\
& $(P=.126)$ & $(P=.836)$ & $(P=.924)$ & \\
\hline
\end{tabular}

The results found from linear regression run to show influence of different occupations on mobile banking adoption rate conclude that though most of the users of mobile banking service are service holders and students, none of the occupations used here have significant impact on mobile banking adoption rate in Bangladesh. In all the cases, $p$ values are sufficiently higher than the significance level of.1.

In conclusion it can be said that the alternative hypothesis of Hypothesis 1 cannot be accepted as the models proved non-significant in all the cases that are used to show influence of demographic profile of users on rate of mobile banking adoption.

\subsection{Mobile Banking Issues: Analysis of Influence of Five Selected Variables}

Overall Percentile Analysis has been done for the responses of mobile banking users to investigate selected factors in mobile banking which may enforce challenges to the providers of mobile banking and thus may influence success of mobile banking in Bangladesh.

Hypothesis 2

Hypothesis 2 is developed to show the influence of users' perception over increase rate of mobile banking in last four years in Bangladesh. To test the hypothesis five independent variables (Trust, Security, Cost and Convenience, Complexity and Network problem) have been used against the dependent variable (Mobile banking adoption rate).

Table 16. Influence of perception on rate of mobile banking adoption.

\begin{tabular}{|c|c|c|c|c|c|}
\hline & Trust & Security & Cost Convenience & Complexity & Network \\
\hline \multirow{3}{*}{$\begin{array}{l}\text { Mobile banking } \\
\text { adoption }\end{array}$} & $\mathrm{b}=28.453$ & $\mathrm{~b}=-83.974$ & $b=179.050$ & $b=-32.585$ & $b=37.695$ \\
\hline & $\mathrm{R}^{2}=.673$ & $\mathrm{R}^{2}=.844$ & $\mathrm{R}^{2}=.808$ & $\mathrm{R}^{2}=.823$ & $\mathrm{R}^{2}=.394$ \\
\hline & $(P=.1791)$ & $(P=.081)$ & $(P=.101)$ & $(P=.093)$ & $(P=.372)$ \\
\hline
\end{tabular}

The results depicted above conclude that security, cost and convenience, and complexity have significant influence over adoption rate of mobile banking in Bangladesh as their $p$ values are lower or close to significance level of. 1 and $R^{2} \mathrm{~S}$ are very close to 1 . Whereas trust and network problem seem to have no influence over the adoption rate of mobile banking as their $p$ values are significantly higher than significance level of.1. Hence security, cost and convenience and complexity can contribute significantly to the variability of rate of mobile baking adoption rate.

In conclusion it can be said as multiple regression is not used because of multicollinearity problem (See Appendix A), the overall significance of the model cannot be drawn. However, using linear regression it can be concluded that security, cost and convenience, and complexity have significant influence over mobile banking adoption rate in Bangladesh.

Findings and discussion from analysis of demographic profile and analysis of Influence of Five Selected variables

The two hypotheses drawn in the study to show the influence of demographic profile of users and their perception over mobile banking adoption are tested using linear regression model instead of multiple regression model because of the presence multicollinearity problem. Demographic profile is shown to have no influence on increase in mobile banking adoption rate of Bangladesh. Gender, age limit and occupation are used to show the demographic profile. Though male occupy a major portion of total customers in market, gender proves to have no dominance over mobile banking adoption because in Bangladesh both male and female are now getting engaged with study and work equally, and they are using mobile banking service irrespective of their gender. Hence a particular gender has no dominance over adopting mobile banking service. In addition, people from all age limits are now using mobile banking for their education, study, occupation, business etc. Therefore, people of a particular age limit do not necessarily have influence over the overall mobile banking adoption rate. Consequently, people from all occupations are increasingly realizing their dependency on the mobile banking. Though the number of users is higher in case of students (268) and service holder (70), the trend 
seems to be increasing in all occupations. So, not a particular occupation seems to have dominance over total mobile banking adoption rate. On the other hand, users' perception over mobile banking is used to show its influence on mobile banking adoption rate. A single conclusion is tough to be drawn as perception regarding different factors has different influence on mobile banking. As people of Bangladesh are more conscious about their security and cost, these two factors seem to have significant influence on mobile banking with $p$ values of.081 and.101. In addition, they have $\mathrm{R}^{2}$ values of.844 and.808 which indicate that much of the variability in mobile banking adoption can be described by these two factors. People of Bangladesh are educationally and technologically less advanced. Complexity in usage may cause decrease in mobile banking usage. The study shows that the model is significant and $p$ value is.093. $\mathrm{R}^{2}$ of this model seems higher which indicate that higher complexity may cause huge decrease in mobile banking usage. Bangladesh is overcoming network problem day by day. All parts of the country are now being tried to cover under network. Hence the perception of network does not necessarily influence mobile banking adoption in Bangladesh.

\subsection{Relationship Between Mobile Banking Usage Score and the Five Underlying Factors}

Findings and discussion from relationship between Mobile Banking Usage Score and the five underlying factors Correlation and multiple regression analyses were conducted to examine the relationship between Mobile Banking Usage Score and the five underlying factors - Trust, Security, Cost and Convenience, Complexity and Network Availability. Table 17 summarizes the analysis results.

Table 17. Relationship between perception and mobile banking usage rate using score model.

\begin{tabular}{ll}
\hline Summary output & \\
\hline Regression Statistics & 0.578132167 \\
\hline Multiple R & 0.334236802 \\
R Square & 0.316793694 \\
Adjusted R Square & 2.536945279 \\
Standard Error & \\
\hline
\end{tabular}

\begin{tabular}{lllll}
\hline ANOVA & & & & \\
\hline & df & SS & MS & F \\
\hline Regression & 5 & 678.5408 & 135.7082 & 21.08549 \\
Residual & 210 & 135.579 & 6.436091 & $4.75893 \mathrm{E}-17$ \\
Total & 215 & 2030.12 & & \\
\hline
\end{tabular}

\begin{tabular}{|c|c|c|c|c|c|c|c|c|}
\hline & coefficient & Standard error & T test & P value & Lower $95 \%$ & Upper $95 \%$ & Lower $95 \%$ & Upper $95 \%$ \\
\hline Intercept & $\mathbf{0}$ & N/A & N/A & N/A & N/A & N/A & N/A & N/A \\
\hline Trust & 0.020741802 & 0.240042 & 0.86409 & 0.931224 & -0.452458671 & 0.493942 & 0.45246 & 0.493942 \\
\hline security & -0.024551335 & 0.326493 & -0.0752 & 0.94013 & -0.668175772 & 0.619073 & -0.66818 & 0.619073 \\
\hline Cost \& convenience & 0.224180824 & 0.193128 & 1.160788 & 0.247046 & -0.15653762 & 0.604899 & -0.15854 & 0.604899 \\
\hline complexity & 0.234521639 & 0.22683 & 1.03391 & 0.302367 & -0.21263352 & 0.681677 & 0.21263 & 0.681677 \\
\hline Network availability & 0.104635584 & 0.275248 & 0.38015 & 0.704218 & -0.43796728 & 0.647238 & -0.43797 & 0.647238 \\
\hline
\end{tabular}

It demonstrates that the factors Trust, Cost and Convenience, Complexity or Ease of use, and Network Availability is positively and significantly correlated with the Usage, indicating that those with higher scores on these variables tend to have higher Usage of M Banking.

However, Security is negatively correlated with $M$ Banking Usage. This paradoxical implication can be interpreted as such that notwithstanding the people with low perceived security on M Banking show higher inclination towards $\mathrm{M}$ Banking usage. The multiple regression model with all five predictors produced $\mathrm{R}^{2}=.3342$, Significance $\mathrm{F}=$ 4.7589326488623E-17.

\section{Conclusion}

Financial institutions are now rearranging the banking industry of Bangladesh and as such Mobile Banking has come in versatile in the market. This is mostly the stipulation of banking and financial services with the help of mobile devices. This platform is updating to offer highly interactive mobile applications that meet the needs of customers. To carry out the research, the authors have conducted the statistical analysis with the help of SPSS: frequency tables, pie charts \& linear regression analysis. Through the research the authors found out that there is a high degree of positive correlation among the independent and dependent variables. It can be assumed that, the adoption and usage of mobile banking in Bangladesh is dependent on various variables like - convenience, network availability, complexity, security and trust. So the mobile banking service providers need to ensure offering this service at cheap cost with high security so that customers feel convenient to use it and can rely on and trust this new dimension of financial inclusion in Bangladesh. 
Appendix A

Table A1. Correlations among Different Age.

\begin{tabular}{|c|c|c|c|c|c|c|c|c|c|}
\hline \multicolumn{10}{|c|}{ Correlations among Different Age } \\
\hline \multirow{7}{*}{$\begin{array}{l}\text { Pearson } \\
\text { Correlation }\end{array}$} & & Accounts & $15-19$ & $20-24$ & $25-29$ & $30-34$ & $35-39$ & $40-44$ & $45-49$ \\
\hline & Accounts & 1 & 0.54 & -0.801 & 0.249 & 0.728 & 0.894 & 0.815 & 0.815 \\
\hline & $20-24$ & -0.801 & -0.062 & 1 & -0.716 & -0.957 & -0.956 & -0.94 & -0.94 \\
\hline & $25-29$ & 0.249 & -0.65 & -0.716 & 1 & 0.596 & 0.481 & 0.474 & 0.474 \\
\hline & $30-34$ & 0.728 & 0.167 & -0.957 & 0.596 & 1 & 0.957 & 0.985 & 0.985 \\
\hline & $40-44$ & 0.649 & 0 & -0.445 & 0.386 & 0.183 & 0.381 & 0.225 & 0.225 \\
\hline & $45-49$ & 0.815 & 0.328 & -0.94 & 0.474 & 0.985 & 0.986 & 1 & 1 \\
\hline \multirow{7}{*}{ Sig (1-tailed) } & Accounts & . & 0.23 & 0.1 & 0.375 & 0.136 & 0.053 & 0.093 & 0.093 \\
\hline & $15-19$ & 0.23 & . & 0.469 & 0.175 & 0.417 & 0.326 & 0.336 & 0.336 \\
\hline & $20-24$ & 0.1 & 0.469 & . & 0.142 & 0.021 & 0.022 & 0.03 & 0.03 \\
\hline & $25-29$ & 0.375 & 0.175 & 0.142 & . & 0.202 & 0.259 & 0.263 & 0.263 \\
\hline & $35-39$ & 0.053 & 0.326 & 0.022 & 0.259 & 0.021 & . & 0.007 & 0.007 \\
\hline & $40-44$ & 0.176 & 0.5 & 0.278 & 0.307 & 0.409 & 0.309 & 0.388 & 0.388 \\
\hline & $45-49$ & 0.093 & 0.336 & 0.03 & 0.263 & 0.008 & 0.007 & . & . \\
\hline \multirow{8}{*}{$\mathrm{N}$} & Accounts & 4 & 4 & 4 & 4 & 4 & 4 & 4 & 4 \\
\hline & $15-19$ & 4 & 4 & 4 & 4 & 4 & 4 & 4 & 4 \\
\hline & $20-24$ & 4 & 4 & 4 & 4 & 4 & 4 & 4 & 4 \\
\hline & $25-29$ & 4 & 4 & 4 & 4 & 4 & 4 & 4 & 4 \\
\hline & $30-34$ & 4 & 4 & 4 & 4 & 4 & 4 & 4 & 4 \\
\hline & $35-39$ & 4 & 4 & 4 & 4 & 4 & 4 & 4 & 4 \\
\hline & $40-44$ & 4 & 4 & 4 & 4 & 4 & 4 & 4 & 4 \\
\hline & $45-49$ & 4 & 4 & 4 & 4 & 4 & 4 & 4 & 4 \\
\hline
\end{tabular}

Table A2. Correlations among Different Occupation。

\begin{tabular}{|c|c|c|c|c|c|c|c|c|c|}
\hline \multicolumn{10}{|c|}{ Correlations among Different Occupation } \\
\hline & & Accounts & Business & service & student & doctor & garments & housewife & None \\
\hline \multirow{8}{*}{$\begin{array}{l}\text { Pearson } \\
\text { Correlation }\end{array}$} & Accounts & 1 & 0.799 & 0.467 & -0.625 & 0.874 & 0.874 & 0.164 & -0.076 \\
\hline & business & 0.799 & 1 & 0.846 & -0.91 & 0.98 & 0.98 & -0.42 & -0.658 \\
\hline & service & 0.467 & 0.846 & 1 & -0.982 & 0.725 & 0.725 & -0.5 & -0.85 \\
\hline & student & -0.625 & -0.91 & -0.982 & 1 & -0.818 & -0.818 & 0.387 & 0.757 \\
\hline & doctor & 0.874 & 0.98 & 0.725 & -0.818 & 1 & 1 & -0.333 & -0.522 \\
\hline & garments & 0.874 & 0.98 & 0.725 & -0.818 & 1 & 1 & -0.333 & -0.522 \\
\hline & housewife & 0.164 & -0.42 & -0.5 & 0.387 & -0.333 & -0.333 & 1 & 0.87 \\
\hline & None & -0.076 & -0.658 & -0.85 & 0.757 & -0.522 & -0.522 & 0.87 & 1 \\
\hline \multirow{8}{*}{ Sig (1-tailed) } & Accounts & . & 0.1 & 0.267 & 0.188 & 0.063 & 0.063 & 0.418 & 0.462 \\
\hline & business & 0.1 & . & 0.077 & 0.045 & 0.01 & 0.01 & 0.29 & 0.171 \\
\hline & service & 0.267 & 0.077 & . & 0.009 & 0.137 & 0.137 & 0.25 & 0.075 \\
\hline & student & 0.188 & 0.045 & 0.009 & . & 0.091 & 0.091 & 0.306 & 0.122 \\
\hline & doctor & 0.063 & 0.01 & 0.137 & 0.091 & . & 0 & 0.333 & 0.239 \\
\hline & garments & 0.063 & 0.01 & 0.137 & 0.091 & 0 & . & 0.333 & 0.239 \\
\hline & housewife & 0.418 & 0.29 & 0.25 & 0.306 & 0.333 & 0.333 & . & 0.065 \\
\hline & None & 0.462 & 0.171 & 0.075 & 0.122 & 0.239 & 0.239 & 0.065 & . \\
\hline \multirow{8}{*}{$\mathrm{N}$} & Accounts & 4 & 4 & 4 & 4 & 4 & 4 & 4 & 4 \\
\hline & business & 4 & 4 & 4 & 4 & 4 & 4 & 4 & 4 \\
\hline & service & 4 & 4 & 4 & 4 & 4 & 4 & 4 & 4 \\
\hline & student & 4 & 4 & 4 & 4 & 4 & 4 & 4 & 4 \\
\hline & doctor & 4 & 4 & 4 & 4 & 4 & 4 & 4 & 4 \\
\hline & garments & 4 & 4 & 4 & 4 & 4 & 4 & 4 & 4 \\
\hline & housewife & 4 & 4 & 4 & 4 & 4 & 4 & 4 & 4 \\
\hline & None & 4 & 4 & 4 & 4 & 4 & 4 & 4 & 4 \\
\hline
\end{tabular}


Table A3. Correlations among Perception.

\begin{tabular}{|c|c|c|c|c|c|c|c|}
\hline \multicolumn{8}{|c|}{ Correlations among Perception } \\
\hline & & account & Trust & security & Convenience & Complexity & Network \\
\hline & Account & 1 & 0.821 & 0.919 & 0.899 & 0.907 & 0.628 \\
\hline & Trust & 0.821 & 1 & 0.919 & 0.696 & 0.8 & 0.472 \\
\hline & security & 0.919 & 0.919 & 1 & 0.688 & 0.972 & 0.346 \\
\hline & Convenience & 0.899 & 0.696 & 0.688 & 1 & 0.631 & 0.905 \\
\hline Pearson & Complexity & 0.907 & 0.8 & 0.972 & 0.631 & 1 & 0.245 \\
\hline \multirow[t]{5}{*}{ Correlation } & network & 0.628 & 0.472 & 0.346 & 0.905 & 0.245 & 1 \\
\hline & Trust & 0.09 & . & 0.041 & 0.152 & 0.1 & 0.264 \\
\hline & security & 0.041 & 0.041 & . & 0.156 & 0.014 & 0.327 \\
\hline & Convenience & 0.051 & 0.152 & 0.156 & . & 0.184 & 0.048 \\
\hline & Complexity & 0.046 & 0.1 & 0.014 & 0.184 & . & 0.378 \\
\hline \multirow[t]{5}{*}{ Sig (1-tailed) } & network & 0.186 & 0.264 & 0.327 & 0.048 & 0.378 & . \\
\hline & account & 4 & 4 & 4 & 4 & 4 & 4 \\
\hline & Trust & 4 & 4 & 4 & 4 & 4 & 4 \\
\hline & Convenience & 4 & 4 & 4 & 4 & 4 & 4 \\
\hline & Complexity & 4 & 4 & 4 & 4 & 4 & 4 \\
\hline $\mathrm{N}$ & Network & 4 & 4 & 4 & 4 & 4 & 4 \\
\hline
\end{tabular}

\section{References}

[1] Alam, M. Z. et al. 2013. Mobile money system: the Bangladesh experience. International Journal of Scientific and Research Publications 3 (10).

[2] Goyal, V. et al. 2012. Mobile banking in India: practices, challenges and security issues. International Journal of Advanced Trends in Computer Science and Engineering 1 (2).

[3] Islam. 2013. Mobile banking: An emerging issues in Bangladesh. ASA University Review, Vol. 7 No 1, JanuaryJune.

[4] Kabir, M. R. 2013. Factors influencing the usage of mobile banking: incident from a developing country. World Review of Business Research 3 (3), pp. 96-114.

[5] Nandhi, M. A. 2012. Effects of mobile banking on the savings practices of low income users - the Indian experience. Institute for Money, Technology and Financial Inclusion working paper series no. 2012-7.

[6] Rahman, M. 2013. Implementation of mobile banking in Bangladesh: opportunities and challenges. IOSR journal of Electronics and Communication Engineering, Vol 7, pp. 5358.

[7] Ramdhony, D. and Munien, S. 2013. An investigation on mobile banking adoption and usage: a case study of Mauritius. World Journal of Social Sciences 3 (3), pp. 197-217.

[8] Saini, G. S. 2014. Mobile banking in India: issues and challenges. Sai Om Journal of Commerce \& Management 1 (3).

[9] Sharma, A and kansal, V. 2012, Mobile banking as technology adoption and challenges: a case of m-banking in India. International Journal of Scientific and Research Publications $2(2)$. 